\title{
The Construction of College English Flipped Classroom - In Terms of Metacognition Theory
}

\author{
Chaoqun Xie ${ }^{a}$, Lihua $X u^{b}$ \\ School of Foreign Languages, Neijiang Normal University, Neijiang 641112, China \\ a2494007404@qq.com, b272924471@qq.com
}

\begin{abstract}
The metacognition, as a psychological theory, has been widely employed in the English teaching. The flipped classroom of college English, as a new mixed teaching model combining English teaching with IT, is highly concerned by English teachers. The application of metacognitive theory to the construction of the flipped classroom of college English helps students not only master related learning strategies to make their metacognitive experience filled with happiness, but also be more proficient in using the cognitive monitoring to adjust own learning.
\end{abstract}

Keywords: metacognitive theory, flipped classroom, college English, construction.

\section{Introduction}

In recent 30 years, various studies on the metacognitive theory have emerged endlessly, which makes a great impact on the educational practice. Flipped classroom, as a new teaching model born in recent 10 years, has attracted the attention of global education. In order to solve previous problems in College English teaching, to enhance college students' English comprehensive ability and College English teachers' teaching efficiency, a large number of foreign language scholars apply the metacognition theory or flipped classroom model to English teaching practice, and they get an outstanding effect, which is not only beneficial to English teaching revolution but also actively keeps pace with the ten-year development plan of educational informationization made by Ministry of Education. Although flipped classroom develops rapidly in America and has been widely accepted by teachers and students, related studies in China are only at the primary stage because of starting late, which causes that there are only few researches probing into the application of metacognition theory into this new kind of college English teaching model, therefore, this paper, on the basis of metacognition theory, discusses how to construct a college English flipped classroom.

\section{Metacognition Theory}

"Metacognition Theory" appeared in the 1970s, put forward initially by Flavell, American renowned child psychologist. Flavell thinks that metacognition is the cognitive subject' knowledge and ability to regulate and control the cognitve activities. Metacognition in the teaching practice is learners' knowledge about cognitive activites in the learning process and the ability to regulate and control these activites. In accordance with Flavell, metacognition includes metacognitive knowledge metacognitve experience ${ }^{1}$. Simply speaking, the former is learners' knowledge about learning subjects and activities, and the latter refers to the emotional experience accompanying with cognitive activities. Flavell's metacognitive knowledge can be divided into three kinds of knowledge: the subject, the task and learning strategies. Brown, American famous linguist, argues that metacognition should embrace metacognitive knowledge but not the metacognitive experience which should be replaced by the metacognitive monitoring. After David Disalvo compares and analyzes Flavell's and Brown's opinions, he deems that metacognitve knowledge, metacognitve experience and metacognitive monitoring jointly and dynamically constitute the metacognition ${ }^{2}$. Learning strategies in the metacognitive theory are also important for English learners, whose influence cannot be ignored. In terms of O'Malley and Chamot's classification, learning strategies include not only cognitive strategy 
but also metacognitive strategy and social-affective strategy, the three of which supplement each other ${ }^{3}$.

\section{Flipped Classroom}

\subsection{Definition of Flipped Classroom}

Flipped classroom, also called as Inverted classroom, is the product of deep combination of information technology and teaching, overturning the traditional class of "teaching" and "learning". In 2007, it was born in America where education is highly free and science and technology is advanced. It was not introduced into China until Salman Khan, the founder of Khan Academy, made a speech entitled "USING VIDEO RESHAPES EDUCATION" in 2011, which drew attention from educational workers at home and abroad ${ }^{4}$. Traditional teaching model centers on teachers imparting knowledge in class, and students' knowledge internalization, mainly through homework and exercises, is put after class. On the contrary, flipped classroom teaching model depends on highly developed computer networking technology. Before class, new knowledge is studied, while the class time is used to complete knowledge internalization. In teaching practice, specifically speaking, before class, students themselves studies teaching videos, teaching plan and other related materials released by teachers through network; in class, teachers mainly help students solve problems in their self learning by means of exercises and teacher-to-student or student-to-student discussions.

\subsection{Features of Flipped Classroom}

Because of reversing traditional teaching model, flipped classroom owns some new features. First, an obvious change takes place in teachers' and students' roles. Teachers shift from the imparter of knowledge into the knowledge provider, while students are changed from the knowledge accepter into the knowledge creator; secondly, place and time of "teaching" and "learning " are changed from school into home, and from in class into after class; thirdly, the teaching of knowledge is finished by students' self study, as well as knowledge internalization takes place in the teacher-student interactions; fourthly, there are more interactions between teacher and students or students and students; lastly, teaching videos and network turn into significant tools of knowledge transmission. Apparently, flipped classroom makes up for the deficiency of traditional teaching model, and replenishes and develops the latter since it is conducive not only to build harmonious relations between teachers and students, but also to foster students' autonomous learning ability and personalized learning. Furthermore, now that this new teaching model uses a plethora of multimedia and network technology, its teaching videos and electronic materials can be utilized repeatedly, which immensely optimizes teaching resources.

\subsection{Flipped Classroom of College English}

China officially started the teaching reform of college English in 2003. The reform requires that the chief goal of English teaching should be to cultivate students' English comprehensive ability and to develop their autonomous learning ability, in addition, it also attaches a great importance on the application of computers in English teaching. Since then, multimedia came to be used widely in college English teaching. However, many colleges and universities still adopt exam-oriented education system, aiming at passing CET 4 and CET 6, as a result, traditional teaching model has not been changed a lot and college English class still focuses on imparting knowledge. Consequently, college students' listening and speaking abilities are not improved in valid, as well as writing ability develops slowly, so, "dumb English" can be seen everywhere. Flipped classroom brings challenges and opportunities to college English reform which is in plight. Wang Shouren, a noted Chinese scholar, has an unique insight into English teaching. He holds that future college English teaching will tend to combine the learner-centered and teacher-guided teaching model with advanced computer and network technology ${ }^{5}$. College English flipped classroom is a mixed teaching model blending English teaching with information technology, which can not only dispose of "dumb English" but also raise students' autonomous learning ability. There are few studies on English flipped classroom in domestic, which are just limited to its theoretical aspect. After having made a feasibility analysis of college English flipped classroom in terms of teacher, student and teaching environment, Lu Haiyan 
considered that flipped classroom can be applied to college English; Zhao Bing \& He Gaoda investigated postgraduate English flipped classroom in the institute of nationalities, and the result manifested that flipped classroom is helpful for students to construct new learning model, and to increase their self-learning, creative and English-using abilities ${ }^{6}$.

\section{Constructing College English Flipped Classroom under the Metacognition Theory}

Scholars at home and abroad discover that the cultivation of metacognition ability contributes to improve English reading, listening, speaking, writing and translation, and that metacognition theory has a positive effect on the construction of flipped classroom. The construction of college English flipped classroom can be divided into three stages: video making, video learning and class exercise. And metacognition theory is mainly used to guide activities in these three stages.

\subsection{Making Teaching Videos}

Flipped classroom is a kind of teaching model mixing video teaching with class exercise. Teaching videos of high quality can focalize students' learning experience but also evoke their learning interest to actively study teaching videos by themselves, hence, video making is quite critical for the successful implementation of the whole class. So, as the maker of teaching videos, college English teachers have to harbor related metacognition knowledge. In line with the metacognition theory, college English teachers ought to have a full understanding of themselves and the task to produce videos. In the first place, teachers should change traditional teaching idea so that they can accept flipped classroom. Then, they should come to a clear realization that it is time for them to convert their role from knowledge imparters to video makers in English teaching, and that whether they are eligible for this role. As for the task to make video, teachers should be aware of its importance, hold an active attitude toward it, and know its specific requirement. Moreover, teachers should know learners' learning condition well, such as English level, major and aptitude, to determine teaching contents which not only reflect key and difficult points but also are closely relevant to teaching aims. In line with Vygotsky's ZPD, teaching videos of college English flipped classroom should offer students learning contents that are higher than their previous English level but not surpass the zone of approximate development, and stimulate students' potential to transcend ZPD to make progress. Lastly, In order to get high-quality teaching videos of college English flipped classroom, teachers have to use cognitive and metacognitive strategies to help themselves finish the task. Before making videos, they can employ planning metacognitive strategies, such as studying multimedia skills, gathering related teaching materials, making teaching plan and designing the procedures of video making; in the process of making video, monitoring and controlling metacognitive strategies are used to monitor mistakes in videos; After making them, the assessment metacognitive strategies are utilized to make a self-introspection and evaluation so as to make progress next time.

\subsection{Learning Teaching Videos}

In flipped classroom, students' video learning directly affects the knowledge internalization in class. How to enhance the efficiency of video learning is key to flipped classroom. There are some problems influencing the efficiency: students are in a low self-learning ability and English level; students are used to the traditional English teaching model, unwilling to try new things; video learning lacks mutual interaction so that learning problems cannot be solved in time, which affects the following study; video learning takes a lot of spare time; students have no interest in English. Like English teachers, students should also have a full understanding of the metacognitive knowledge of flipped classroom at first, including their own merits and demerits, learning tasks, related learning strategies, to change own attitude towards English learning so that they can insure the new teaching model better. Then, they put metacognitive theory into practice. For instance, when meeting problems in video learning, students can turn to cognitive strategies such as playing teaching contents repeatedly, noting down problems and asking for others' help. In the process of fostering autonomous learning ability, both teachers and students can use metacognitive strategies to plan, monitor and assess it. Besides, English teachers may 
design their teaching videos according to the multimoding theory so that students' metacognitive experience of English video learning becomes more pleasant.

\subsection{Class Exercise}

Social-affective strategy in the metacognitive theory means that in order to complete learning tasks, learners turn to people or objects or self control to adjust own emotion, attitude and motivation toward learning, for example, students make discussions about their learning problems. This strategy are not only useful to eliminate students' negative metacognitive emotional experience, but also to augment the chance to use language, which is crucial to English learning. In Traditional college English class, teachers pay much attention to the knowledge transmission of English language and grammar, and overlook the cultivation of comprehensive ability to use English and students 'social affection. However, the class time in flipped classroom is taken to explain key and difficult teaching points students put forward by the teacher firstly, and then students in groups discuss own problems in video learning through different activities, meanwhile, the teacher participate in them. In this class, teachers and peers play a scaffolding role, which can help students evolve into ZPD and finish knowledge internalization. Additionally, Since this kind of cooperative learning class increases teacher-to student and student-to-student interactions, relationships between teachers and students are improved and more chances to use English are provided. Some scholars hold that improper teaching conditions and lack of help will lead to weak learning performance, therefore, when teachers organize English activities, they should create more opportunities for students to use social-affective strategies such as cooperative learning, solving problems, disposing of anxiety and regulating learning moods. Teachers themselves should employ this kind of strategies reasonably in teaching, too. For example, when teachers make a comment on students' performance, words used by them should be positive so that students can become more confident of their study.

\section{Conclusion}

As the mixed carrier of English teaching and multimedia technology, college English flipped classroom keeps in line with the tendency of educational informatization in China, reflecting the essence of language teaching, namely, fostering students' ability to use language. The metacognition theory not only offers theoretical basis to the construction of college English flipped classroom but also raises its teaching efficiency. Owing to limited resources, this paper just discusses the guiding impact of metacognition theory on the construction of college English flipped classroom, and future studies should focus on empirical ones of college English reading, writing, spoken English, translation and listening flipped classroom. With the deepening of English teaching reform, certainly, there are more and more people studying flipped classroom and the influence on it made by metacognition theory.

\section{Acknowledgments}

This work was financially supported by a grant from Education Department of Sichuan (No. 15SB0142).

\section{References}

[1] Flavell, J.H.Metacognition and Cognitive Monitoring: A New Area of Cognitive Developmental Inquiry [J]. American Psychologist, 1979, (10): 906-911.

[2] Disalvo, David. Metacognition: Changing Brain Mindset [M]. Translated by Shu Chen. China Machine Press, 2014.

[3] O’Malley,J.M., Chamot, A.U. Learning Strategies in Second Language Acquisition [M]. Shanghai: Shanghai Foreign Language Education Press, 2001.

[4] Haiyan Lu. Feasibility Analysis on the Application of Micro-class Based "Flipped Classroom" Mode in College English Teaching [J]. Computer-Assisted Foreign Language Education, 2014, (7): 33-36. 
[5] Shouren Wang, Haixiao Wang. On the State of College English Teaching in China and Its Future Development [J]. Foreign Languages in China, 2011, (9): 4-17.

[6] Bing Zhao, Gaoda He. Explorative Research on Flipped Classroom in Graduate English of the Minority University [J]. Technology Enhanced Foreign Language Education, 2015, (11): 76-80. 